\title{
Critical Factors for Optimum Biodegradation of Bast Fiber's Gums in Bacterial Retting
}

\author{
Mohammad Munir Hossain ${ }^{1,2} \mathbb{D}$, Shafiquzzaman Siddiquee ${ }^{1, *(\mathbb{D})}$ and Vijay Kumar ${ }^{1}$ (D) \\ 1 Biotechnology Research Institute, Universiti Malaysia Sabah, Jalan UMS, \\ Kota Kinabalu 88400, Sabah, Malaysia; DZ1721009A@student.ums.edu.my (M.M.H.); \\ vijay@ums.edu.my (V.K.) \\ 2 Bangladesh Jute Research Institute, Manik Mian Avenue, Dhaka 1207, Bangladesh \\ * Correspondence: shafiqpab@ums.edu.my; Tel.: +60-149-294-481
}

Citation: Hossain, M.M.; Siddiquee,

S.; Kumar, V. Critical Factors for Optimum Biodegradation of Bast Fiber's Gums in Bacterial Retting. Fibers 2021, 9, 52.

https://doi.org/10.3390/fib9080052

Academic Editor: Vincenzo Fiore

Received: 7 April 2021

Accepted: 28 June 2021

Published: 12 August 2021

Publisher's Note: MDPI stays neutral with regard to jurisdictional claims in published maps and institutional affiliations.

Copyright: () 2021 by the authors. Licensee MDPI, Basel, Switzerland. This article is an open access article distributed under the terms and conditions of the Creative Commons Attribution (CC BY) license (https:// creativecommons.org/licenses/by/ $4.0 /)$.

\begin{abstract}
Bast fiber plants require a post-harvest process to yield useable natural cellulosic fibers, denoted as retting or degumming. It encompasses the degradation of the cell wall's non-cellulosic gummy substances (NCGs), facilitating fibers separations, setting the fiber's quality, and determining downstream usages. Due to the inconvenience of traditional retting practices, bacterial inoculum and enzyme applications for retting gained attention. Therefore, concurrent changes of agroclimatic and socioeconomic conditions, the conventional water retting confront multiple difficulties, bast industries become vulnerable, and bacterial agents mediated augmented bio-retting processes trying to adapt to sustainability. However, this process's success demands a delicate balance among substrates and retting-related biotic and abiotic factors. These critical factors were coupled to degrade bast fibers NCGs in bacterial retting while holistically disregarded in basic research. In this study, a set of factors were defined that critically regulates the process and requires to be comprehended to achieve optimum retting without failure. This review presents the bacterial strain characteristics, enzyme potentials, specific bast plant cell wall's structure, compositions, solvents, and interactions relating to the maximum NCGs removal. Among plants, associated factors pectin is the primary biding material that determines the process's dynamics, while its degree of esterification has a proficient effect through bacterial enzymatic degradation. The accomplished bast plant cell wall's structure, macerating solvents $\mathrm{pH}$, and temperature greatly influence the bacterial retting process. This article also highlights the remediation process of water retting pollution in a biocompatible manner concerning the bast fiber industry's endurance.
\end{abstract}

Keywords: non-cellulosic gums; bacterial retting; degumming enzymes; pectin esterification; retting factors; macerating solvent

\section{Introduction}

Natural fibers as raw materials have gained momentum, attributed to their unique characteristics in numerous biocompatible commodities preparations. These fibers surmounted hazardous petroleum-based materials, requiring optimum fiber quality and those quality parameters inclined by growing conditions, retting, and other processing [1-3]. The raw fiber applications in numerous downstream uses differ concerning fiber quality consistency, i.e., chemical, or mechanical properties, mostly from retting [4,5].

It is the most intricate and obligatory process for producing natural cellulosic fiber from heterogeneous bast fiber plants. Along with the separation feasibility of cellulosic bast fibers from the intact binding of pants cell wall matrix through the elimination of non-cellulosic gummy substances (NCGs), increased favorable mechanical properties eventually validated the multiple value-added green commodities preparations. It improves the cellulose composition of fibers. Elimination of NCGs results in disaggregating the pectin-lignin matrix bounds the elementary fibers and produces fiber bundles. It enhances the wettability of fibers and their compatibility with the polar functional groups of the 
polymeric matrix, improving the adhesion to the polymer matrix, forming a more robust interface and therefore improved composite accomplishments [6]. The most prominent drawback of using natural cellulose fiber in biocomposites preparation is its inconsistent fiber quality, mostly inclined from the retting process. An effective bio-retting method encompasses the maximum elimination of NCGs within the least retting period. Subsequently, an effective degumming process could produce the desired cellulose fibers necessary to utilize fiber concerning economic aspects and fiber quality [7-9]. Unprocessed fibers carry admixtures of NCGs, which increased volumetrically thick fiber bundles. This fraction did not accept the loads transferred across the fiber-matrix interface uniformly cross section, thus determining a reduction in the effective fiber volume fraction [10]. Besides these, the targeted biocomposites preparations such as sound absorption insulation materials, automobile, and aeronautical interior decorative materials, virgin-grade packaging materials achieved after effective elimination of NCGs through the retting process [11,12].

Existing retting approaches confront inconsistent fiber quality, pollution, and input deficit issues, consequently driving to search for alternative retting processes. However, the proliferation of variable quality attributes from under retting and over retting leads to internal fiber rot with low strength and remains gummy substances unblemished, respectively [13,14]. More extended degumming periods (14-28 days) carry a risk of damaging cellulose and yield lower fiber mechanical properties. The dispersion of retting effluents such as galacturonic acid, butyric acid, acetic acid, lactic acid, $\mathrm{Ca}^{2+}, \mathrm{Mg}^{2+}$, bicarbonate content, and aquatic ecosystem alters the aquatic flora and fauna [15-18]. Because of worldwide climatic changes, low or lopsided precipitation crushes the accessibility of vast water sources. These disadvantages are unequivocally interlinking with the fiber quality, cultivator's benefits, and generally, the bast fiber industry's endurance.

Innovative retting approaches, such as chemical, mechanical, osmotic, ultrasound, and microwave, were attempting to yield fiber; notwithstanding, every alternative has its impediments concerning pollution and significant expense [19-21]. The microbial solutions, for example, commencement of expected bacterial agents, either live strains or enzymes in the retting cycle, have demonstrated a plausible procedure yet request some basic conditions for their ideal initiation. Among different retting components, for example, bast plants, bacteria, solvents, and related biotic and abiotic elements requires a fragile equilibrium to break up the intact binding of cell wall polysaccharides network for quality fiber recuperation. Choices of fitting bacterial strains dependent on their ideal enzymatic potentials, growth characteristics, gums qualities, and other related variables are examined here. The bacterial retting associated critical factors that are obligatorily required for attaining maximum biodegradation of bast fibers adhering NCGS were conferred here. Along with this typical bacterial augmented bio-retting process, its alternative practices of the process were also discussed. This finding may assist with finding appropriate elements for bast fiber bacterial retting measure.

\section{Innovative Degumming Approaches}

Several augmented approaches devoid of biological retting had opted eliminating the natural cellulose fibers adhering NCGs for desired quality fiber. The goals of simulated techniques are set to faster completion of the process, leveraging conventional retting disadvantages. To date, each augmented process has its limitation, and comparably sophisticated approaches require additional input cost and accomplished with chemical hazards, barely can tolerate the endurance of bast industries competing with synthetic materials. In addition, those techniques were not feasible to maintain the large volume of bast mass; consequently, at the grower's level, they are still beyond reality. Some innovative techniques are presents in Table 1; those could be the alternative to retting. Besides these, specific target-oriented product manufacturing sectors use fiber surface modification techniques to make it compatible with other commodities such as silane treatment, maleic anhydride grafted polypropylene (MAPP) treatment; electron beam irradiation (EBI) technique, graft co-polymerization, and mercerization; and etherification are few to name. 
Table 1. Some innovative degumming approaches showed potential to be used as an alternative to the bio retting process.

\begin{tabular}{|c|c|c|}
\hline Methods & Key Features & Ref. \\
\hline Hydrothermal treatment & $\begin{array}{l}\text { The designed hydrothermal treatment usually involves the reaction of steam, } \\
\text { device runs at a certain water temperature coupled with steam pressure. }\end{array}$ & {$[7,22-26]$} \\
\hline Ultrasonic treatment & $\begin{array}{c}\text { Ultrasonic treatment accomplished with vibrating sound at certain } \\
\text { physiochemical conditions }\end{array}$ & [27] \\
\hline Chemical treatment & $\begin{array}{l}\text { Applications of acid or base solution for degumming generally uses } \mathrm{HCl} \text {, } \\
\mathrm{H}_{2} \mathrm{SO}_{4} \text { as acid solvents and } \mathrm{NaOH} \text { or } \mathrm{KOH} \text { alkali solution. Along with this } \\
\mathrm{KMnO}_{4}, \mathrm{~K}_{2} \mathrm{Cr}_{2} \mathrm{O}_{7}, \mathrm{H}_{2} \mathrm{O}_{2} \text {, and } \mathrm{NaClO}_{2} \text { were also proved potentiality as } \\
\text { degumming agents. }\end{array}$ & {$[22,28]$} \\
\hline $\begin{array}{l}\text { Mechanical eprocessing } \\
\text { and decortication }\end{array}$ & $\begin{array}{c}\text { Complete machine line processing includes pick-up and cutting of plants mass, } \\
\text { bales up to cleaning the final products, fibers, and shives processing of } \\
\text { non-retted plants. }\end{array}$ & [29] \\
\hline Deep eutectic solvents (DESs) & $\begin{array}{c}\text { Utilization of DESs method coupled with microwave and } \\
\text { alkaline-ultrasonic treatment. }\end{array}$ & {$[30,31]$} \\
\hline
\end{tabular}

\section{Bacterial Retting Process}

Utilizing bacterial retting agents is to inoculate specific bacterial strains or enzymes into the controlled or semi-controlled retting niches. Conversely, conventional retting happens by naturally developed microbiota in open field conditions. A schematic perspective on bacterial agents' intervened retting measure is presented in Figure 1.

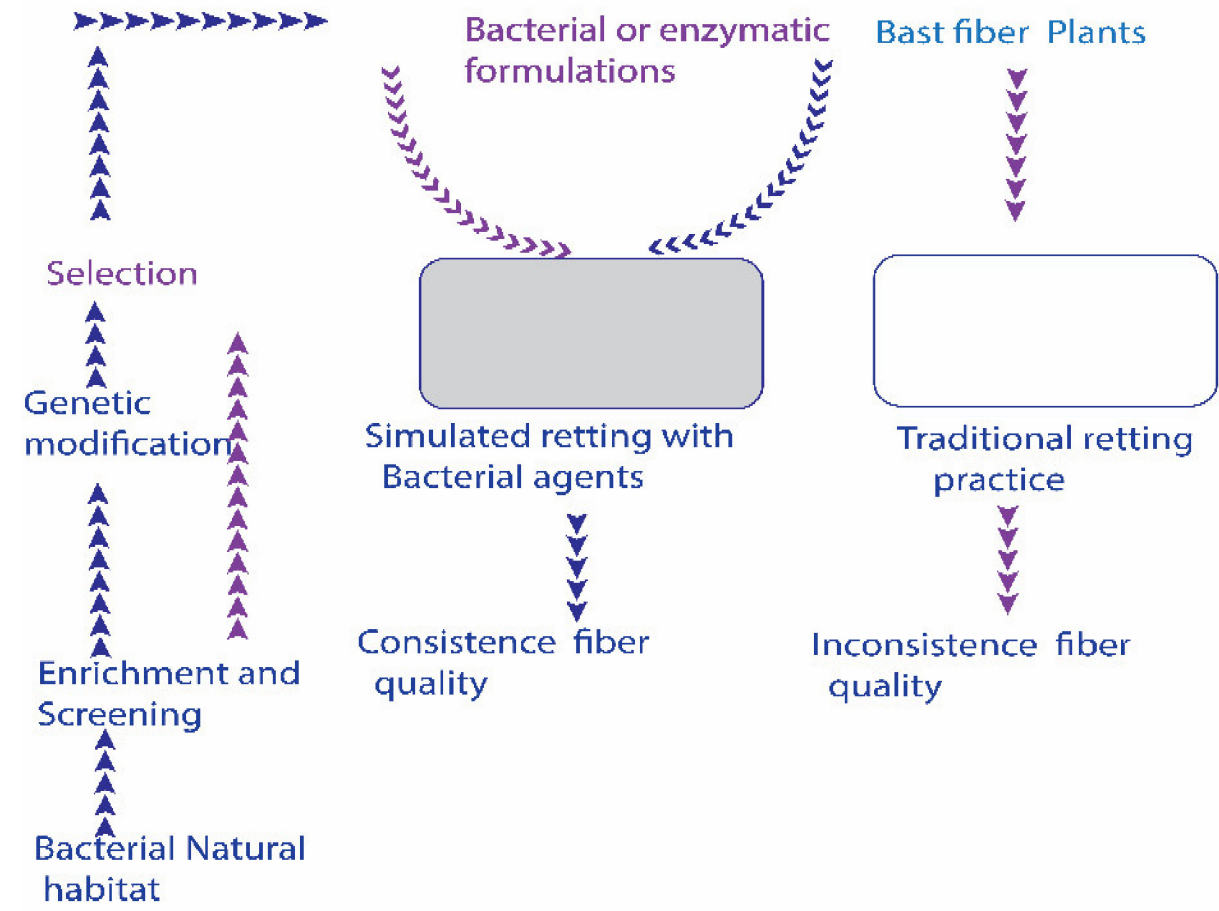

Figure 1. A possible scheme for incorporating bacterial bio-retting agents (enzymes + bacterial formulations) into non-sterile bast fiber retting niche. Inoculation of alkaline strains additionally surpasses the growth of unwanted endogenous bacteria. The establishment of a mechanized controlled retting niche could improve the retting process.

Macerating solvents, mainly water and bacterial extracellular enzymes combine to act on the insoluble plants' surface. Bacterial enzymes initiate long-chain breaks in the cell wall gummy substances without the need to extricate these chains from their crystalline lattice. The significant strides of retting are water ingestion, an arrangement of calcium oxalate crystals; cortex expulsion; evacuation of gum in the center lamella and the fiber surfaces. The initial two cycles were finished under low enzyme activation, while the third cycle 
required maximum pectinase activity, and the last cycle commenced with higher pectinase and xylanase activities $[32,33]$. This retting process preserves the original carbohydrate structure in monomeric sugars, compared to the chemical destruction of the carbon, which possesses the upper limit of cellulose, however, a lesser lignin content [34].

\section{Bast Fiber Cell Wall Structure Influencing Bacterial Retting}

Cellulosic bast fibers originate from a particular gelatinous kind secondary cell wall of dicotyledonous plants. The key features of this sort of cell wall are their high substance of cellulose accomplishing $(85 \%)$, existing and contrasted with the classic xylan type cell wall [35-38]. Usually, the bast fibers cell wall average width is 4 to $10 \mu \mathrm{m}$; therefore, with the help of macerating solvents, bacteria successfully can break the cell wall barrier to invade [39]. The elementary fibers are reinforced along with pectin's and lignin outlining the following microstructure level, i.e., specialized technical fibers, with a distance across going from 50 to $100 \mu \mathrm{m}$ [40]. The primary cell wall is just 0.02 micrometers thick and made of lignin and pectin, and is a haphazardly situated cellulosic fiber, though the secondary cell wall is dominated by cellulose attached together with lignin and hemicellulose (Figure 2).

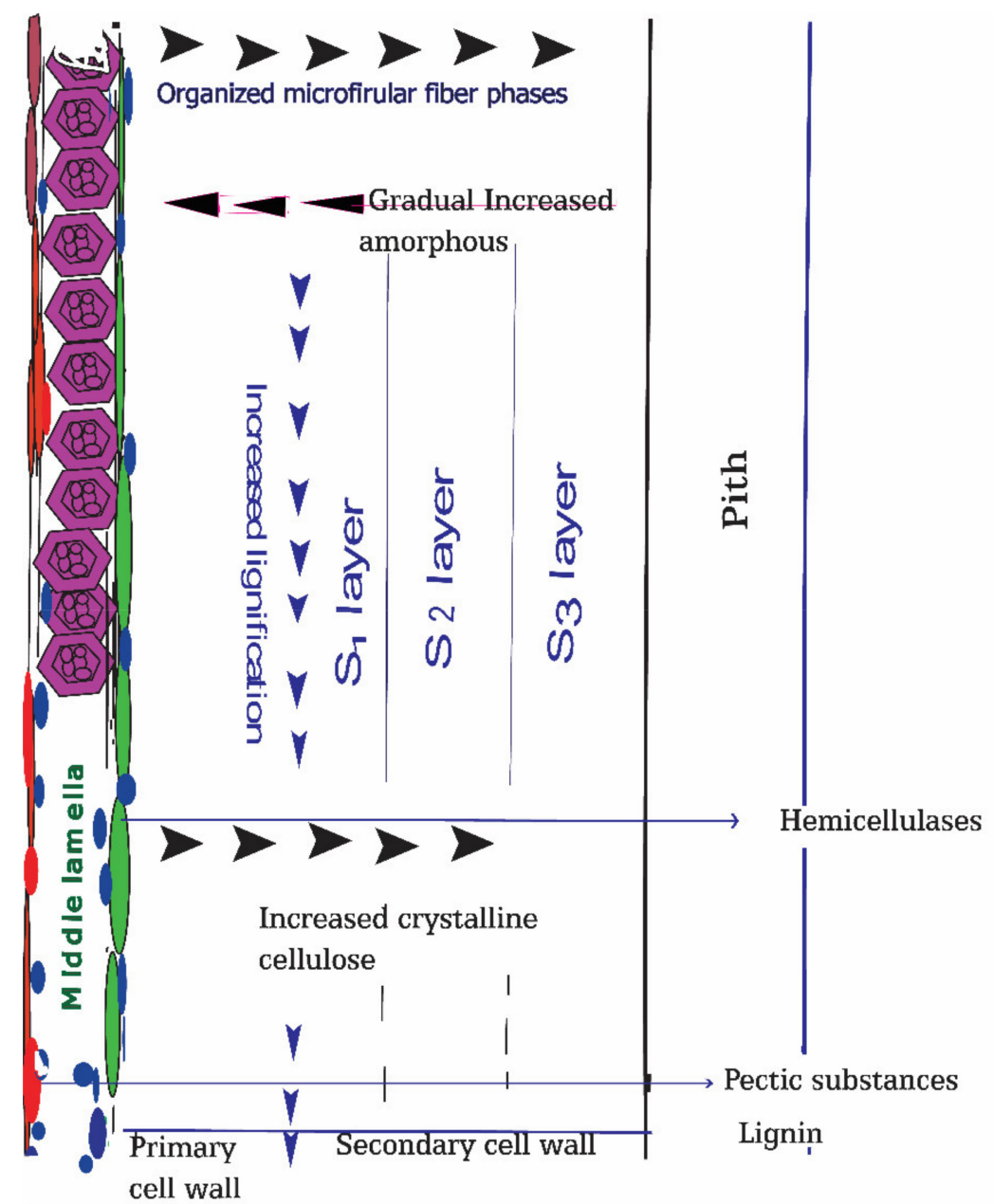

Figure 2. Schematic representation of bast fiber plants cell walls and their compositions. Biodegradation of cell walls components at retting process is beneath their proportion of crystalline and amorphous structures and deposited gums concentrations such as degree of lignification and degree of pectins esterification.

The classical xylan-rich cell wall acts as the percussor of bast fibers gelatinous type cell wall [41]. Due to hygroscopic nature of xylan, this type of a cell wall tends to degrade faster 
than those made of crystalline cellulose fiber. The presence of Rhamnogalacturonans-I in the gelatinous-type secondary cell walls effectively retained by cellulose microfibrils with separate layers termed as S1, S2, and S3 according to the order of their deposition. During the quick growth cycle of plant production, the most invasive noticeable output of primary bast fibers occurs [42]. Fiber cell formations were categorized in two distinct phases: (a) expansion devoid of new stratum buildup called the primary cell wall and (b) step of cell wall setting designated as secondary walls [43].

Cellulose accomplishes its most important focus in the S2 layer, and lignin accumulates in the center lamella and organized gathering in groups, isolated by the cortex parenchyma cell with the pectin and hemicellulose rich cell wall [44]. Among three secondary cell wall layers, S2 is the more robust and determines the fiber properties. As cell wall structure and the bast fiber component's orientation vary, the non-cellulosic gums in correlation with cellulosic fibers also vary in different positions. The outer, middle lamella is rich in pectic substances and lignin, which plays a crucial role in maceration and, subsequently, microbial invasion, and acts as an enzymatic epicenter. The organized fiber structure with crystalline compositions increases from the middle lamella to the secondary cell wall. Conversely, amorphous cell wall components were prevalent at outer, middle lamella and tended to decrease towards inner portions.

Different arrangement of crystalline in cellulose structure are brought about by intra and intermolecular hydrogen holding, which happened through hydroxyl bunches [45]. There are 90-100 ' $\mathrm{g}$ ' crystalline cellulose $(\mathrm{I} \beta) / 100 \mathrm{~g}$ cellulose observed in plant-based fibers [46]. Thus, the proportional orientation of bast components such as outer amorphous components degrade faster, and the inner crystalline cellulosic components take time to decompose. A proper level of retting within a minimum time is essential [47] which gave the protection to the crystalline cellulosic fiber rather than amorphous gums.

\section{Bast Fibers Cell Walls Constituents Affecting Retting Process}

Bast fibers chemical constituents are categorized as major and minor groups. The main constituents for which the plants are domesticated are natural cellulose fiber, along with hemicellulose and lignin. On the other hand, pectic substances, ash, proteins, pigments, different extractives, and mineral constituents such as $\mathrm{Ca}$ and $\mathrm{Mg}$. However, pectic materials present in trace quantities but determine the adhesive, mechanical, and defensive functions of bast fiber plants. Consequently, the separation of individual fiber through the retting process from a fiber bundle depends on the degradation of these pectic substances. The cellulose and lignin together shared for more than $60 \%$ and, at times, up to $80 \%$ of the secondary cell walls which also contain hemicelluloses and relatively less pectin compares to primary cell walls [48,49]. Major constituents of commercially important bast fibers are shown in Table 2.

Table 2. Major cell wall compositions of commercially cultivated bast fiber plants (\%).

\begin{tabular}{cccccc}
\hline Bast Fiber & Cellulose & Hemicellulose & Lignin & Pectin & Ref. \\
\hline Jute & $59-72$ & $12-20$ & $12-13$ & $2-4$ & {$[42]$} \\
Kenaf & 53.18 & 14.33 & 8.18 & 8.86 & {$[43]$} \\
Hemp & $60-70$ & $15-20$ & $2-4$ & 4 & {$[44]$} \\
Ramie & $69-85$ & $13-17$ & $5-7$ & 2 & {$[40]$} \\
Flax & $62-72$ & $17-21$ & $2-5$ & $2-3$ & {$[50]$} \\
\hline
\end{tabular}

Cellulose is the repeating linear form of glucose unit composed of $\beta-1$, four linkages. Based on chemical composition, cellulose is the main component (50-99\%) of all bast fibers. The percentage of cellulosic compositions differs from plant types and even varietal differences, determining the quality, and end use of fiber. Indication of retting reflects by removing its amorphous portions, which increases the crystallinity of that fiber. These single subunits together create a larger unit of microfibrils. The linkages throughout the microfibrils are closely interlinked, providing them with the excellent mechanical property. 
This hydrogen bond between the two cells with a mostly parallel cellulose layer is connected tightly and wrapped microfibrils. The microfibrils are then added to the crystalline cellulose fibers. Degradation of cellulosic components during retting destroys fibers. Crystalline cellulose portions could be beneficial for high-quality fiber; conversely, critical parts of cellulosic fragments gave lower fiber yield. Chemically, 17.5 percent of $\mathrm{NaOH}$ solutions are used to produce $\alpha$-cellulose. The modern $X$-ray diffractometer technology determines the crystallinity of cellulosic fiber. Its proportion with other incrusted substances determines the fiber quality, mainly attributed to retting. The crystalline structure of cellulose protects it from degradation for a prolonged retting period.

The second abundant component of bast fiber is hemicellulose, which comprises complex branched groups of polysaccharide constituents with $\mathrm{H}$-bonding to cellulose. These mixtures are sugar units such as xylan, xyloglucan, 4-methyl glucuronic acid, mannans, galacturonic acid, arabinogalactan, or other heteropolysaccharides residues. Galactoglucomamman is the major structural component of bast fibers hemicellulose. Differential characteristics of hemicellulose from cellulose include their degree of polymerization and lower weight. A higher proportion of hemicellulose conversely increases its water retention characteristics and made the fiber lower quality. The hemicellulosic cross-linking network considers the main structural constituent of the fiber cell. During the retting process, this fraction is not entirely removed by retting, and its proportion determines the crystallinity of cellulosic fiber. One of the significant functions of hemicellulase is to maintain the biodegradable characteristic of the fiber.

Pectin is the polymer of D-galacturonic acid residues originating from the middle lamella of the primary cell wall. Pectin is the chief incrusting material and the deciding factor for the retting, holding fiber bundles together with other cell wall components, ranging from 5 to 23 percent [51,52]. The middle lamella of bast fiber is the determinant hub of retting, where fiber cells are glued together with pectineus gums. This individual fiber makes the fiber bundles parallelly orientated to the stem's longitudinal axis. Galactose composition is the typical gelatinous type of cell wall, also known as galactan and arabinogalactan. Pectin is one of nature's most diverse biomacromolecules. In pectin structures, there are seventy different monosaccharide units, and seven different polysaccharides units observed. Pectineus substances differ from origins, which are inclined to esterified proportions (methylated) of total galacturonic unit contents. Its esterified variation demands specific pectinolytic enzymes to depolymerize $[53,54]$.

Lignin consists of complex aliphatic and aromatic hydrocarbon polymers, and it generates powerful cellulose and hemicellulose clusters in plant materials. Lignification of bast fibers increases with the plants' age and differs from sources, becoming more condensed than the hardwood fiber lignin [55-57]. The hydrophobic lignin network distresses another network's attributes so that it acts as a linking negotiator and surges the rigidity of the fiber to make composites materials [58]. The full removal of lignin from the bast fiber cellulose portions during retting is a difficult task. Lignification in bast materials increases with the plants' age and makes the fiber hard and whitish color. Conversely, delignification improves its color and reduces pore sizes, which is ideal for biocomposites materials. Another positive aspect of delignification is the reduced compositions of a hemicellulose-oriented acetyl group [59].

A trace amount of wax, protein, soluble gums, and minerals components were also present on to cell walls of bast fibers, which could also play a role in the retting process. The most prominent roles play the cell walls calcium and magnesium minerals, combining with pectins forms $\mathrm{Ca}$ or $\mathrm{Mg}$ pectate. That pectate trapped the cellulose fiber on to the cell wall hard binding. Insoluble waxes are made of various alcohols and can extract with organic solutions.

\section{Bacterial Strains Affecting Retting Process}

All biological bast fiber retting processes are exclusively functions of microbial enzymatic activities. With the help of solvent maceration, bacteria penetrate the cell wall 
tissues through stomata by replacing intercellular air. The primary critical factors for choosing to ret potential bacteria depend on their optimal growth for specific nutrient requirements, temperature, $\mathrm{pH}$, and $\mathrm{O}_{2}$ status. Spore-forming bacteria can survive in harsh environmental conditions and their extracellular enzymes are highly stable.

Plants endogenous bacterial mixture is non-selective, and their specific roles yet to be explored. In mixed microbial niche, some microbes secrete specific enzymes, and the rest of them areas non-producers, but all the microbes take nutrients from the sources for their metabolic activities. The non-enzyme producers are described as microbial cheaters and showed that higher costs of enzymes production favor cheaters and lower rate favored producers [60]. The co-existence of cheaters and producers is highly organized but releases intermediate-level enzymes. Therefore, competition from non-selective cheaters is believed to result in inefficient enzyme production. On the other hand, nutritional limitations can restrict the microbial fostering and enzymatic degradation of heterogeneous lignocellulosic materials in natural atmospheres. The concept of bacteria applications in the retting process arises because of the tumbling efficiency of existing practices. Bacterial inoculum, whether natural selections or genetically modified strains, should reach the grower's level as safe, be user-friendly, and have the potential to be stored for an extended period. Infrastructure related to bacterial retting was accomplishing with an artificial retting tank made of the cemented permanent tank, plastic tank, or temporary soil digging tank wrapping with plastic. Experimental retting tanks for fiber plants gave satisfactory results, both sterile and non-sterile retting at a research-level. The digestion of the lignocellulosic material by bacterial means in a controlled fermentation niche is a proven technology, however, it is still at the beginning phase for retting purposes.

Inoculation of these bacterial agents may serve to control the microbial diversity in the retting niche. Aerobic bacterial flora begins the retting process and continues if there prevails enough $\mathrm{O} 2$ for these bacteria's sustenance. After that, anaerobic bacterial strains actively operate the retting process to the end. Till now, there was no evidence to use anaerobic stains as a starter inoculum. Facultatively anoxic strain actively participated in the retting process in both aerobic and anaerobic conditions. It is still debatable that a single isolate could complete the retting process or not, as multiple enzymes require retting completion. Application of bacterial consortia gave influential retting performances comparing to inoculation of single strains. Another possible solution could be the initiation of numerous enzymatic potentials strains. A list of retting potentials bacterial strains presents in Table 3.

Table 3. List of potentials bacterial strains uses for bast fiber retting.

\begin{tabular}{|c|c|c|c|c|c|}
\hline Bacteria & Strain & Enzymes & Optimum pH & Optimum Temp. & Ref. \\
\hline Bacillus sp. & $\begin{array}{l}\text { NT-39, 53, } 76 \\
\text { MG-cp-2 }\end{array}$ & $\begin{array}{l}\text { PL, XL, } \\
\text { PG, Lac }\end{array}$ & 10 & $45^{\circ} \mathrm{C}, 60^{\circ} \mathrm{C}$ & [61-63] \\
\hline B. Pumilus & $\begin{array}{l}\text { NRRL B-212, } \\
\text { ATCC } 7061\end{array}$ & Exo-pectinase & - & - & {$[64,65]$} \\
\hline B. subtilis & EFRL 01 & PG & 8 & $45^{\circ} \mathrm{C}$ & {$[66]$} \\
\hline B. licheniformis & $\begin{array}{c}\text { HDYM-03 } \\
\text { KIBGE IB-21, SHG10, DSM-13 }\end{array}$ & PL, PG, PNL & - & - & [67-70] \\
\hline B. Cereus & HDYM-02 & PG & - & - & [71-73] \\
\hline B. megaterium & $\begin{array}{l}\text { HDYM-09 } \\
\text { AK2 }\end{array}$ & PNL & - & - & {$[67,74]$} \\
\hline B. clausii & - & - & - & - & [75] \\
\hline B. tequilensis & $\begin{array}{l}\text { SV11-UV37 } \\
\text { CAS-MEI-2-33 }\end{array}$ & $\begin{array}{l}\text { PL, PG } \\
\text { P }\end{array}$ & 10 & $40^{\circ} \mathrm{C}$ & {$[76,77]$} \\
\hline B. halodurans & M29 & - & & - & {$[78]$} \\
\hline B. mojavensis & M14, & - & - & - & [79] \\
\hline $\begin{array}{c}\text { Enterobacteriaceae Pectobacterium sp., } \\
\text { Enterobacter lignolyticus }\end{array}$ & DCE-01, SCF1 & $\begin{array}{l}\mathrm{P}, \mathrm{MN}, \mathrm{XL} \\
\mathrm{Lac}\end{array}$ & - & $35^{\circ} \mathrm{C}$ & {$[80,81]$} \\
\hline
\end{tabular}

$\mathrm{P}=$ pectinase, $\mathrm{PG}=$ Polygalacturonase, $\mathrm{PL}=$ pectatelyase, $\mathrm{PNL}=$ Pectin lyase, $\mathrm{XL}=$ Xylanase, $\mathrm{MN}=$ mananase, $\mathrm{Lac}$ : Laccases ' - ' $=$ Not mentioned. 
Inoculation of bacteria strains decreases the other bacterial richness and diversity. The inoculated strain led to replacing different non-retting potentials bacterial strains; dominant groups are all degumming enzyme producers and survive until completion of retting. Application of pectinolytic bacteria as consortia gave superior retting results compared to single strains due to multiple enzymes requirement to degrade cell wall gummy substances $[32,82,83]$. The main groups of bacteria that help to degrade lignin are Actinomycetes, Firmicutes, Bacteroides, and Proteobacteria [84-86]. In several studies it was observe that the formulation of bacterial consortia in retting gave influential outcome comparing with using single strain. A list of bacterial consortia are presents in Table 4 .

Table 4. Bacterial consortia made for promoting bast fiber retting.

\begin{tabular}{|c|c|c|c|}
\hline Bacterial Consortia & Composition & Enzymatic Potentials & Ref. \\
\hline CRIJAF SONA & $\begin{array}{l}\text { Bacillus sp (PJRB1-Acc. No. MTCC 5573, } \\
\text { PJRB2-MTCC 5574, and PJRB3-MTCC 5575) }\end{array}$ & PG, PNL and Xylanase & [83] \\
\hline RAMCD407 & P. aeruginosa, Enterococcus sp., B. subtilis, Bacillus sp. & $\begin{array}{l}\text { Pectinase, xylanase } \\
\text { and mananase }\end{array}$ & [32] \\
\hline C-51, C-67, and C-90 & $\begin{array}{c}\text { B. megaterium, B. subtilis, B.s cereus, B. xiamenensis, B. } \\
\text { koreensis, } P \text {. mirabilis, E. tabaci, K. oryzae, S. } \\
\text { nematodiphila and Aeromonasjandaei. }\end{array}$ & Pectinase and Xylanase & [82] \\
\hline $\mathrm{MC} 1, \mathrm{MC} 2, \mathrm{MC} 3$ & $\begin{array}{l}\text { B. subtilis B.s pumilus IMAU80221, B. pumilus GVC11 } \\
\text { and B. pumilus SYBC-W }\end{array}$ & Pectinase & {$[16,20]$} \\
\hline
\end{tabular}

\section{Bacterial Retting Enzymes Affecting Retting Process}

In the retting process, enzymes' applications gave consistent fiber quality, restricted fiber damage, minimum or no fiber impurities, reduced odor, and retting pollution. Simultaneously, enzymatic breakdown of natural fibers matrix by pectinases, hemicellulase, and laccases is less invasive. Bast fiber biological retting is indeed the function of bacterial or fungal enzymes [87]. Besides utilization of available commercial enzymes in retting could modify fiber characteristics as demanded properties that benefit bast fiber processing and fabric finishing ecology. Enzymatic separation produces stronger fiber suitable for textile applications [88-90].

A group of diversified enzymes acts on pectin substances by cleaving the pectin chain's 1,4-glycosidic bonds. So far, there have been records of 15 different types of pectinase. There have been several studies to investigate the effectiveness of pectinase on the bast fiber retting. As retting is the transformation of pectin [87,91], pectinases are the main retting enzyme. Based on its optimal $\mathrm{pH}$ activity, i.e., acid, and alkaline pectinases generally obtain from fungal and bacterial sources, respectively. Treating bast fibers with pectinase improves the mechanical characteristics of reinforced thermoplastic composites [92,93]. Alkaline pectinase has applications in the textile sector for bio-scouring and retting. Among alkali tolerant enzymes, polygalacturonase is the prime enzyme involved in the bast fiber retting process $[61,94]$, including pectin lyase, pectate lyase, and esterase. When selecting pectinases, one should consider their esterification degree, as their polymerization and solubility depend on it. [95]. Pectinase applications modify other non-cellulose plants gums, such as 3\% pectinase application at kenaf retting reduced around one-half of the syringyl and guaiacyl lignin [96]. Beyond this, the possible reason is pectin, and hemicellulase of bast materials restricts the same uronic acid content [97]. Depolymerization reaction of pectic substances hangs on their chosen substrates, degradation mechanisms either trans-elimination or hydrolysis, cleavage mechanism either random for endo-acting or terminal for exo-acting enzymes [98]. A list of retting pectinases and their mode of actins presents in Table 5. 
Table 5. List of bacterial enzymes involved in the biodegradation of non-cellulosic bast fibers gum in classical bacterial retting process.

\begin{tabular}{|c|c|c|c|c|c|c|}
\hline $\begin{array}{l}\text { Name of } \\
\text { Enzymes }\end{array}$ & Enzyme Types & Common Name & $\begin{array}{l}\text { E. C. Suggested } \\
\text { No. }\end{array}$ & Substrate & Cleavage Mechanism & Product \\
\hline \multirow{4}{*}{$\begin{array}{c}\text { Pectinases } \\
\text { (Depolymerizes) }\end{array}$} & \multirow[t]{2}{*}{ Hydrolases } & $\begin{array}{l}\text { Exo-polygalacturonases } \\
\text { (Exo-PG1 or PG }\end{array}$ & 3.2 .1 .67 & Pectate & $\begin{array}{l}\text { Catalyze the } \alpha-1,4 \\
\text { glycosidic linkage }\end{array}$ & mono galacturonate \\
\hline & & $\begin{array}{l}\text { Exo-polygalacturonases } \\
\text { (Exo-PG2 or P.G.) }\end{array}$ & 3.2.1.82 & Pectate & Act on end cleaving site & Di galacturonate's \\
\hline & $\begin{array}{c}\text { Lyases: } \\
\text { (Polygalacturonate } \\
\text { Lyase (PGL) }\end{array}$ & $\begin{array}{c}\text { Pectate lyases } \\
\text { (Exo-PGL or P.L.) }\end{array}$ & 4.2.2.9 & Pectin & Act on end site bonds & $\begin{array}{l}\text { Unsaturated Di } \\
\text { galacturonate's }\end{array}$ \\
\hline & $\begin{array}{c}\text { Lyases: Polymethyl } \\
\text { galacturonate Lyase } \\
\text { (PMGL) }\end{array}$ & $\begin{array}{c}\text { Pectin lyases } \\
\text { (Exo-PMGL or PNL) }\end{array}$ & 4.2 .2 .10 & Pectin & Random cleavage & $\begin{array}{l}\text { Unsaturated methyl } \\
\text { oligo galacturonate }\end{array}$ \\
\hline $\begin{array}{c}\text { Pectinases } \\
\text { (De-esterifying) }\end{array}$ & Esterase & $\begin{array}{l}\text { Polymethyl galacturonate } \\
\text { esterase (PMGE or PME) }\end{array}$ & 3.1.1.11 & Pectin & $\begin{array}{l}\text { Random modification of } \\
\text { ester group }\end{array}$ & $\begin{array}{l}\text { Pectin acid and } \\
\text { methanol }\end{array}$ \\
\hline Hemicellulose & Hydrolases & Xylanase & 3.1.1.8 & $\begin{array}{l}\text { Xylan } \\
\text { Mannan }\end{array}$ & $\begin{array}{l}\text { Cleavage } \beta-1,4 \\
\text { glycosidic linkage }\end{array}$ & xylose \\
\hline Cellulase & Hydrolases & Endoglucanase & 3.2.1.4 & $\begin{array}{l}\text { Amorphous } \\
\text { Cellulose }\end{array}$ & $\begin{array}{l}\text { Nonreducing end of the } \\
\text { cellulose chain }\end{array}$ & glucose \\
\hline Laccase & Peroxidases & $\begin{array}{c}\text { Laccase } \\
\text { Mn peroxidase }\end{array}$ & $\begin{array}{c}1.10 .3 .2 \\
1.11 .1 .13\end{array}$ & Lignin & 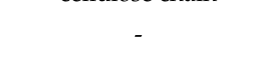 & p-quinone \\
\hline
\end{tabular}

The production and application of pectinase from recombinant microbial sources have increased many folds over the last decades. A single-cell prokaryotic production of enzymes from genetically manipulated bacteria is always preferential due to their known genetic configuration. Whereas fungal sources pectinases are acidic and mainly uses in food sectors. The recombinant alkaline pectinases from Bacillus clausi, Penicilliums sp. 0602, Bacillus halodurans, and Bacillus lichiniformis were reported by several authors in the E. coli expression system and observed their increased enzyme activity $[78,99,100]$.

Bacillus species prominently produce pectinase because of their alkali tolerance, and their cheap fermentation process. Alkaline Bacillus species are salt-loving bacteria, such as $B$. subtilis gave maximum pectate lyase activity by using ammonium salt as nitrogen sources from [101]. Bacterial species belonging to the multiple enzymes encoding genes such as, polygalacturonase from Bacillus licheniformis stain number KIBGE-IB21 contain other auxiliary enzymes such as pectin lyase and pectin methyl esterase with trace amounts of cellulase [68].

Next to pectinases, hemicellulase is the second most important enzyme to contribute in the bast fiber retting process. Among different hemicellulases, xylanases are well characterized and act on the linear backbone of xylan. These hydrolytic enzymes degrade the lignocellulosic interphasic bast fibre xylan through retting process by cleaving $\beta-1-4-$ $D$-xylosidic bond. A list of commercial enzymes use in bast fiber retting and processing shows in Table 6.

Table 6. List of commercial enzymes use in bast fiber retting and processing.

\begin{tabular}{ccc}
\hline Product & Producers & Activities \\
\hline ScourzymeL & Novozymes & PG, PL \\
Bioprep 3000L & Novozymes & P \\
Texazym BFE & Inotex & P \\
Texazym SCW INOTEX Ltd., & Inotex & P, Xy, EG \\
Texazym DLG & Inotex. & Xy, CeB, EG, LPO \\
Texazym SER-3 & Inotex & P, Xy, EG \\
Texazym SER-4 & inotex & P, Xy, EG, CeB \\
Texazym SER-5 & inotex & P, Xy, EG, CeB and Lip \\
Baylase EVO & Lanxess & P \\
Lyvelin & Lyven & P \\
\hline P= pectinase, PG = polygalacturonase, PL = pectin lyase, Xy $=$ xylanase, Eg = Endoglucanase, CeB = Cellobiohy- \\
drolases, Lip = Lignin peroxidase.
\end{tabular}

Bast fiber xylan properties identify as arabinose-4-O-methylglucuronoxylan which typically occurs in softwood fibre plants. Usually, the xylanases are in diversified as like their 
substrate and works on specific substrates. Cellulase-free and alkaline resistant xylanase enzymes favor the retting process. In contrast to fungal origins, bacterial xylanase is alkalitolerant, which is convenient for bast fiber retting. Bacillus species are also well known for their alkali tolerant cellulase free xylanases [62]. Other bacterial sources of xylanase reported from Clostridium cellulovorans, Erwinia spp., Bacillus halodurans, Bacillus circulan.

In general, cellulases for retting purposes consider as detrimental for the primary cellulosic bast fiber. The two different forms of cellulose, i.e., crystalline and amorphous, are degraded by differential cellulases. However, complete degradation of cellulose requires multiple cellulase enzymes. Usually, cellulose is insoluble and crystalline. Therefore, it tends to be nondegradable at a certain retting period whereas endoglucanases act on amorphous regions of the cellulose to degrade its glycosidic linkages'; the amorphous portions are not desired into the cellulosic fiber. In contrast, exo-glucanase or cellobiohydrolases acts on the crystalline portions of cellulosic bast fiber and strongly prohibited for retting purposes. A combination of cellobiohydrolases and endoglucanases entirely degrades the crystalline portions of cellulose [102]. Scarification of this crystalline requires only a small mix of these enzymes. Among bacterial species, cellulase production is dominant in clostridium species with xylanase and or pectinases. Therefore, for retting purposes, cellulase-free xylanase and pectinase enzymes are preferential. A Clostridium strain C. cellulovorans genome study confirms its non-cellulolytic gene encoding hemicellulose and pectinase degrading enzymes [103].

Laccases including phenol oxidase, laccase, and peroxidases are lignin degrading enzymes. There are three peroxidases identified involved in lignin degradation: lignin peroxidase, manganese peroxidase, and flexible peroxidase. As phenolic hydroxyl groups linked together by ether bonds in lignin molecules, useful lignin biodegrades must be broken down this to degrade lignin. In comparison to other microbial lignin sources, bacterial lignin has a high temperature tolerance in salty, alkaline environments [104], which also favor pectin degradation. A new class of lignin peroxides known as dye-decolorizing peroxides was prominent in bacteria assumed have potentiality in the retting process. There are three classes of ligninolytic bacteria identified, i.e., actinobacteria, $\alpha$-proteobacteria, and $\gamma$-proteobacteria, prevalently harbors in the aquatic ecosystem [105]. Laccases are oxidases with a wide range of aromatic compounds such as phenolic, amine hydroxy idols, and benzenethiols. Bacterial sources of Laccases are reported from Bacillus subtilis, Streptomyces lavendulae, and Sinorhizobium meliloti. Lignin peroxidase non-specifically degrades its polymers and is known as true laccase for its superior redox potentiality. The bacterial sources lignin peroxidases are abundant in actinobacteria and streptomyces. Manganesedependent peroxidases were predominantly found in Bacillus and Panebacillilus species.

\section{Interaction of Others Retting Factors}

The bast plant's age has a pivotal role in bacterial retting, as its composition changes at different growth stages. Over matured bast plants have gone through a coarse lignification process; therefore, lignin's composition becomes denser. Comparing with the elongated portion, the base of the plants got more lignin than other parts. Physiochemical properties bast plants with ages have changed, such as fiber diameter increases with maturity, but primary cellulose content and moisture decrease. The other non-cellulosic components might be increases, and water reduction made it hard to swell up while enzymatic degradation [106]. The harvesting period of jute plants for optimum retting and fiber quality between 110 to $120 \mathrm{DAS}$; overmature plants take a more extended period and yield low-quality fiber [107]. Exposed to a long day photoperiod during growing season, bast fiber crops attain faster growth before flowering. Therefore, the green stem at vegetative maturity tends to ret faster and continues up to flower initiation. Harvest time toward the start of seed development prompted easier decortication with no recognizable effect on the fibers' strength. [108]. Therefore, the critical harvest time for optimum bio-retting of bast plants at flowering or before flowering stages, long before the seed maturity [109-111]. Harvesting at this stage also beneficial for products damping characteristics, which hap- 
pened due to increased lignin concentration [112]. The lignin and pectin content relies on their age and maturity, about half that of the cores of roots, and the same level as in the matured samples plants more than 50 days old plants fiber $[113,114]$.

The biodegradation cycle of bast fiber gummy segments influenced by the temperature as it straightforwardly influences the microbial development and metabolic action of proteins. Most of the retting potentials bacteria are optimally grown in between 25 to $35{ }^{\circ} \mathrm{C}$, which ideal for bacterial water retting helps to maintain fiber quality [115]. However, in temperate regions, the field retting process lingers more than two months due to a lack of optimal microbial growth conditions.

Uses of alkaliphiles in retting are advantageous due to their adaptive mechanisms and extracellular stable enzymes in harsh environmental conditions. They are incredibly functioning in these punitive retting environments by maintaining a cytoplasmic $\mathrm{pH}$ for their adaptions between the gradient of the medium. Interestingly, alkaliphiles' intracellular enzymes are like non-alkaliphiles [116,117]. At the beginning, pH of the retting media decreases as low as 4.6-4.9; when the acid dispersion from the biochemical conversion of cell wall materials ended, the retting media again tended to increase the $\mathrm{pH}$. This critical point indicates retting completion after that expects over retting [118]. Commercial enzymes and chelators mediated retting were unable to sequestering $\mathrm{Ca}$ from fiber parts at lower $\mathrm{pH}$ but higher $\mathrm{pH}$ confirm successful retting [119]. In bio retting calcium particles unequivocally hinder plant tissue mellowing at acid $\mathrm{pH}$, yet not in the non-enzymatic acid hydrolysis [120].

Chelating agents are substances that respond with metal particles to shape a steady water-solvent complex. Cell wall minerals components such as $\mathrm{Ca}$ and $\mathrm{Mg}$ make their corresponding Ca or Mg pectate through the "egg box" structure. Therefore, applications of Ca sequestering agents such as EDTA, oxalic acid, phosphorus, and nitrogenous compounds as a chelator in the retting niche, advances the retting process. Cell wall's minerals reacts with chelating agents such as EDTA, oxalic acid, phosphorous, and nitrogen and makes corresponding water-soluble complexes. Optimum activation of pectinase with 18 mM EDTA gave superior fiber quality comparing with no EDTA treatment [121]. Alkali tolerant pectinases play a crucial role in retting by preventing contamination, permits to adopt an open retting system [122-124].

\section{Conclusions}

The excellence and applicability of bast fibers rely upon its effective retting measures, and at present, most of the bast fiber production hubs faced difficulties in achieving it. However, chemicals and other augmented retting require an additional cost and engaged in adulteration. Application of bacterial agents, either live formulations or enzymes, could promote the bast industry numerous ways. This approach surmounted some prevalent difficulties that face the conventional retting processes. The incorporation of bacterial strains in the bio retting process is comparatively novice in practice, while its best patterns yet to be optimized for the demanded outcome. The optimum NCGs degradation required the controlled retting niches rather than steeping in natural aquatic habitats. However, maximizing its efficiency must be further investigated through the manipulations of its core components. Inoculation of multienzyme potentials recombinant strains might be the best choice. In this case, facultative alkaliphilic anaerobes prevented endogenous strains even at non-sterile conditions. Bast plant's pectins are highly esterified (DE: 50), while optimum NCGs degradations were positively correlated with least DE. Therefore, genetically modified low esterified plants could ease the retting difficulties. Though not comprehensively tested, alkaline pectinase with a higher temperature tolerance was worthy for the retting process, which could also be originated from plant sources while their specific roles for retting yet to be examined. However, the enzymatic retting has proven its potency for achieving desired quality fiber while its application is limited due to high cost. Macerating solvents are another critical component of the bio retting process; in recent years, the conventional retting process has been facing difficulties in the availability 
of freshwater solvents for steeping fiber plants due to changing agroclimatic conditions. Therefore, feasibility studies of alternative water solvents such as seawater and municipal wastewater as retting solvents could also be worthy of investigation. In addition, the desired retting within the minimum retting period was obligatory for quality bast fiber and applications of any triggering elements such as $\mathrm{Ca}$ sequestering chelating agents benevolent for the process.

Author Contributions: M.M.H. conceptualization, prepared the manuscript and rewriting, S.S. planning and proof reading, and V.K. editing the manuscript. All authors discussed the writing concept agreed to approve the manuscript. All authors have read and agreed to the published version of the manuscript.

Funding: The research was funded by National Agricultural Technology project 2, (Project ID: P149553) of the Peoples Republic of Bangladesh.

Institutional Review Board Statement: Not applicable.

Informed Consent Statement: Not applicable.

Data Availability Statement: Not applicable.

Acknowledgments: Authors thank to IFAD and World Bank-funded National Agricultural Technology project-2, of the Peoples Republic of Bangladesh for financial support conducting research and Biotechnology Research Institute of Universiti Malaysia Sabah is providing all research facilities.

Conflicts of Interest: The authors have declared that there is no conflict of interest exist.

\section{References}

1. Ramesh, M.; Palanikumar, K.; Reddy, K.H. Plant fibre-based bio-composites: Sustainable and renewable green materials. Renew. Sustain. Energy Rev. 2017, 79, 558-584. [CrossRef]

2. Zimniewska, M.; Wladyka-Przybylak, M.; Mankowski, J. Cellulosic bast fibers, their structure and properties suitable for composite applications. In Cellulose Fibers: Bio- and Nano-Polymer Composites; Springer Science and Business Media LLC: Berlin/Heidelberg, Germany, 2011; pp. 97-119.

3. Shekar, H.S.; Ramachandra, M. Green composites: A review. Mater. Today Proc. 2018, 5, 2518-2526. [CrossRef]

4. Sisti, L.; Totaro, G.; Vannini, M.; Celli, A. Retting process as a pretreatment of natural fibers for the development of polymer composites. In Smart Polymer Nanocomposites; Springer Science and Business Media LLC: Berlin/Heidelberg, Germany, 2018; pp. 97-135.

5. Tezara, C.; Siregar, J.P.; Lim, H.; Fauzi, F.; Yazdi, M.H.; Moey, L.; Lim, J. Factors that affect the mechanical properties of kenaf fiber reinforced polymer: A review. J. Mech. Eng. Sci. 2016, 10, 2159-2175.

6. Sisti, L.; Totaro, G.; Vannini, M.; Fabbri, P.; Kalia, S.; Zatta, A.; Celli, A. Evaluation of the retting process as a pre-treatment of vegetable fibers for the preparation of high-performance polymer biocomposites. Ind. Crop. Prod. 2016, 81, 56-65. [CrossRef]

7. Han, G.; Jiang, W.; Li, X.; Zhang, X.; Zhang, Y.; Li, M. Effect of steam pressure on chemical and structural properties of kenaf fibers during steam explosion process. BioResources 2016, 11, 6590-6599. [CrossRef]

8. Keller, A.; Leupin, M.; Mediavilla, V.; Wintermantel, E. Influence of the growth stage of industrial hemp on chemical and physical properties of the fibres. Ind. Crop. Prod. 2001, 13, 35-48. [CrossRef]

9. Mediavilla, V.; Leupin, M.; Keller, A. Influence of the growth stage of industrial hemp on the yield formation in relation to certain fibre quality traits. Ind. Crop. Prod. 2001, 13, 49-56. [CrossRef]

10. Mazzanti, V.; Pariante, R.; Bonanno, A.; de Ballesteros, O.R.; Mollica, F.; Filippone, G. Reinforcing mechanisms of natural fibers in green composites: Role of fibers morphology in a PLA/hemp model system. Compos. Sci. Technol. 2019, 180, 51-59. [CrossRef]

11. Sánchez-Safont, E.L.; Aldureid, A.; Lagarón, J.M.; Gamez-Perez, J.; Cabedo, L. Biocomposites of different lignocellulosic wastes for sustainable food packaging applications. Compos. Part B Eng. 2018, 145, 215-225. [CrossRef]

12. Santoni, A.; Bonfiglio, P.; Fausti, P.; Marescotti, C.; Mazzanti, V.; Mollica, F.; Pompoli, F. Improving the sound absorption performance of sustainable thermal insulation materials: Natural hemp fibres. Appl. Acoust. 2019, 150, 279-289. [CrossRef]

13. Fernando, D.; Thygesen, A.; Meyer, A.S.; Daniel, G. Elucidating field retting mechanisms of hemp fibres for biocomposites: Effects of microbial actions and interactions on the cellular micro-morphology and ultrastructure of hemp stems and bast fibres. BioResources 2019, 14, 4047-4084. [CrossRef]

14. Ahmed, Z.; Nizam, S.A. Jute-Microbiological and biochemical research. Plant Tissue Cult. Biotechnol. 2008, 18, 197-220. [CrossRef]

15. Majumdar, B.; Chattopadhyay, L.; Barai, S.; Saha, A.R.; Sarkar, S.; Mazumdar, S.P.; Saha, R.; Jha, S.K. Impact of conventional retting of jute (Corchorus spp.) on the environmental quality of water: A case study. Environ. Monit. Assess. 2019, 191, 440. [CrossRef] [PubMed] 
16. Das, B.; Chakrabarti, K.; Ghosh, S.; Majumdar, B.; Tripathi, S.; Chakraborty, A. Effect of efficient pectinolytic bacterial isolates on retting and fibre quality of jute. Ind. Crop. Prod. 2012, 36, 415-419. [CrossRef]

17. Paridah, M.T.; Basher, A.B.; SaifulAzry, S.; Ahmed, Z. Retting process of some bast plant fibres and its effect on fibre quality: A review. BioResources 2011, 6, 5260-5281.

18. Liu, M.; Ale, M.T.; Kołaczkowski, B.; Fernando, D.; Daniel, G.; Meyer, A.S.; Thygesen, A. Comparison of traditional field retting and Phlebia radiata Cel 26 retting of hemp fibres for fibre-reinforced composites. AMB Express 2017, 7, 1-15. [CrossRef] [PubMed]

19. Kavuthodi, B.; Sebastian, D. Biotechnological valorization of pineapple stem for pectinase production by Bacillus subtilis BKDS1: Media formulation and statistical optimization for submerged fermentation. Biocatal. Agric. Biotechnol. 2018, 16, 715-722. [CrossRef]

20. Das, S.; Majumdar, B.; Saha, A.R. Biodegradation of Plant Pectin and Hemicelluloses with Three Novel Bacillus pumilus Strains and Their Combined Application for Quality Jute Fibre Production. Agric. Res. 2015, 4, 354-364. [CrossRef]

21. Chauhan, S.; Sharma, A.K.; Jain, R.K. Enzymatic retting: A revolution in the handmade papermaking from Calotropis procera. In Biotechnology for Environmental Management and Resource Recovery; Springer Science and Business Media LLC: Berlin/Heidelberg, Germany, 2013; pp. 77-88.

22. Song, Y.; Jiang, W.; Nie, K.; Zhang, Y.; Ben, H.; Han, G.; Ragauskas, A.J. An alkali-free method to manufacture ramie fiber. Text. Res. J. 2018, 89, 3653-3659. [CrossRef]

23. Gao, S.; Han, G.; Jiang, W.; Zhang, Y.; Zhang, X. Steam explosion and alkali-oxygen combined effect for degumming of kenaf fiber. BioResources 2015, 10, 5476-5488. [CrossRef]

24. Song, Y.; Jiang, W.; Zhang, Y.; Ben, H.; Han, G.; Ragauskas, A.J. Isolation and characterization of cellulosic fibers from kenaf bast using steam explosion and Fenton oxidation treatment. Cellulose 2018, 25, 4979-4992. [CrossRef]

25. Narkpiban, K.; Poonsawat, T. Optimizing cellulose extraction from kenaf (Hibiscus Cannabinus L.) fiber by selective retting and hydrothermal pretreatment. J. Nat. Fibers 2020, 1-14. [CrossRef]

26. Konczewicz, W.; Zimniewska, M.; Valera, M.A. The selection of a retting method for the extraction of bast fibers as response to challenges in composite reinforcement. Text. Res. J. 2017, 88, 2104-2119. [CrossRef]

27. Klein, J.M.; de Lima, V.S.; da Feira, J.M.C.; Camassola, M.; Brandalise, R.N.; Forte, M.M.D.C. Preparation of cashew gum-based flocculants by microwave- and ultrasound-assisted methods. Int. J. Biol. Macromol. 2018, 107, 1550-1558. [CrossRef]

28. Guo, A.; Sun, Z.; Satyavolu, J. Impact of chemical treatment on the physiochemical and mechanical properties of kenaf fibers. Ind. Crop. Prod. 2019, 141, 111726. [CrossRef]

29. Munder, F.; Furll, C. Effective processing of bast fiber plants and mechanical properties of the fibers. In Proceedings of the 2004 ASAE Annual Meeting, Ottawa, OT, Canada, 1-4 August 2004. [CrossRef]

30. Nie, K.; Liu, B.; Zhao, T.; Wang, H.; Song, Y.; Ben, H.; Ragauskas, A.J.; Han, G.; Jiang, W. A facile degumming method of kenaf fibers using deep eutectic solution. J. Nat. Fibers 2020, 1-11. [CrossRef]

31. Yang, F.; Ma, Y.; Qian, Y.; Lv, L.; Zheng, L.; Zhao, Y. A novel ionic liquid degumming process for Apocynum venetum. J. Text. Inst. 2015, 107, 1450-1455. [CrossRef]

32. Mao, K.; Chen, H.; Qi, H.; Qiu, Z.; Zhang, L.; Zhou, J. Visual degumming process of ramie fiber using a microbial consortium RAMCD407. Cellulose 2019, 26, 3513-3528. [CrossRef]

33. Tamburini, E.; Leon, A.G.; Perito, B.; Mastromei, G. Characterization of bacterial pectinolytic strains involved in the water retting process. Environ. Microbiol. 2003, 5, 730-736. [CrossRef]

34. Jankauskienė, Z.; Butkute, B.; Gruzdevienė, E.; Ceseviciene, J.; Fernando, A.L. Chemical composition and physical properties of dew- and water-retted hemp fibers. Ind. Crop. Prod. 2015, 75, 206-211. [CrossRef]

35. Gorshkova, T.A.; Gurjanov, O.P.; Mikshina, P.; Ibragimova, N.N.; Mokshina, N.E.; Salnikov, V.V.; Ageeva, M.V.; Amenitskii, S.I.; Chernova, T.E.; Chemikosova, S.B. Specific type of secondary cell wall formed by plant fibers. Russ. J. Plant Physiol. 2010, 57, 328-341. [CrossRef]

36. Hobson, N.; Roach, M.J.; Deyholos, M.K. Gene expression in tension wood and bast fibres. Russ. J. Plant Physiol. 2010, 57, 321-327. [CrossRef]

37. Gurjanov, O.P.; Ibragimova, N.N.; Gnezdilov, O.; Gorshkova, T. Polysaccharides, tightly bound to cellulose in cell wall of flax bast fibre: Isolation and identification. Carbohydr. Polym. 2008, 72, 719-729. [CrossRef]

38. Liu, M.; Fernando, D.; Daniel, G.; Madsen, B.; Meyer, A.S.; Ale, M.T.; Thygesen, A. Effect of harvest time and field retting duration on the chemical composition, morphology and mechanical properties of hemp fibers. Ind. Crop. Prod. 2015, 69, 29-39. [CrossRef]

39. Abbott, D.W.; Boraston, A.B. Structural biology of pectin degradation by enterobacteriaceae. Microbiol. Mol. Biol. Rev. 2008, 72, 301-316. [CrossRef] [PubMed]

40. Prasad, B.M.; Sain, M.M. Mechanical properties of thermally treated hemp fibers in inert atmosphere for potential composite reinforcement. Mater. Res. Innov. 2003, 7, 231-238. [CrossRef]

41. Gorshkova, T.; Brutch, N.; Chabbert, B.; Deyholos, M.; Hayashi, T.; Lev-Yadun, S.; Mellerowicz, E.J.; Morvan, C.; Neutelings, G.; Pilate, G. Plant fiber formation: State of the art, recent and expected progress, and open questions. Crit. Rev. Plant Sci. 2012, 31, 201-228. [CrossRef]

42. Mokshina, N.; Chernova, T.; Galinousky, D.; Gorshkov, O.; Gorshkova, T. Key stages of fiber development as determinants of bast fiber yield and quality. Fibers 2018, 6, 20. [CrossRef]

43. Meshram, J.H.; Palit, P. Biology of industrial bast fibers with reference to quality. J. Nat. Fibers 2013, 10, 176-196. [CrossRef] 
44. Ouajai, S.; Shanks, R. Solvent and enzyme induced recrystallization of mechanically degraded hemp cellulose. Cellulose 2006, 13, 31-44. [CrossRef]

45. Sheltami, R.M.; Abdullah, I.; Ahmad, I.; Dufresne, A.; Kargarzadeh, H. Extraction of cellulose nanocrystals from mengkuang leaves (Pandanus tectorius). Carbohydr. Polym. 2012, 88, 772-779. [CrossRef]

46. Thygesen, A.; Oddershede, J.; Lilholt, H.; Thomsen, A.B.; Ståhl, K. On the determination of crystallinity and cellulose content in plant fibres. Cellulose 2005, 12, 563-576. [CrossRef]

47. Henriksson, G.; Akin, D.E.; Slomczynski, D.; Eriksson, K.-E.L. Production of highly efficient enzymes for flax retting by Rhizomucor pusillus. J. Biotechnol. 1999, 68, 115-123. [CrossRef]

48. Komuraiah, A.; Kumar, N.S.; Prasad, B.D. Chemical composition of natural fibers and its influence on their mechanical properties. Mech. Compos. Mater. 2014, 50, 359-376. [CrossRef]

49. Mellerowicz, E.J.; Sundberg, B. Wood cell walls: Biosynthesis, developmental dynamics and their implications for wood properties. Curr. Opin. Plant Biol. 2008, 11, 293-300. [CrossRef]

50. Vignon, M.; Dupeyre, D.; Garcia-Jaldon, C. Morphological characterization of steam-exploded hemp fibers and their utilization in polypropylene-based composites. Bioresour. Technol. 1996, 58, 203-215. [CrossRef]

51. Vignon, M.R.; Garcia-Jaldon, C. Structural features of the pectic polysaccharides isolated from retted hemp bast fibres. Carbohydr. Res. 1996, 296, 249-260. [CrossRef]

52. Yu, H.; Yu, C. Influence of various retting methods on properties of kenaf fiber. J. Text. Inst. 2010, 101, 452-456. [CrossRef]

53. Schols, H.; Coenen, G.; Voragen, A. Revealing Pectin's Structure; Pectins and Pectinases: Wageningen, The Netherlands, 2009; pp. 19-34.

54. Aritkhodzhaev, K.A.; Arifkhodzhaev, A.O.; Yusupov, A.M. Pectin from green kenaf bast. Chem. Nat. Compd. 1995, 31, 159-162. [CrossRef]

55. Day, A.; Ruel, K.; Neutelings, G.; Crônier, D.; David, H.; Hawkins, S.; Chabbert, B. Lignification in the flax stem: Evidence for an unusual lignin in bast fibers. Planta 2005, 222, 234-245. [CrossRef]

56. Suzuki, H.; Macdonald, J.; Syed, K.; Salamov, A.; Hori, C.; Aerts, A.; Henrissat, B.; Wiebenga, A.; Vankuyk, P.A.; Barry, K.; et al. Comparative genomics of the white-rot fungi, Phanerochaete carnosa and P. chrysosporium, to elucidate the genetic basis of the distinct wood types they colonize. BMC Genom. 2012, 13, 444. [CrossRef] [PubMed]

57. Ajith, S. Bacterial degradation of lignin: A prospective for lignocellulosic biofuels. Int. J. Innov. Sci. Res. Technol. $2019,4,11$.

58. John, M.J.; Anandjiwala, R.D. Recent developments in chemical modification and characterization of natural fiber-reinforced composites. Polym. Compos. 2008, 29, 187-207. [CrossRef]

59. MacDonald, J.; Doering, M.; Canam, T.; Gong, Y.; Guttman, D.S.; Campbell, M.M.; Master, E.R. Transcriptomic responses of the softwood-degrading white-rot fungus Phanerochaete carnosa during growth on coniferous and deciduous wood. Appl. Environ. Microbiol. 2011, 77, 3211-3218. [CrossRef] [PubMed]

60. Allison, S.D. Cheaters, diffusion and nutrients constrain decomposition by microbial enzymes in spatially structured environments. Ecol. Lett. 2005, 8, 626-635. [CrossRef]

61. Zhang, J.; Henriksson, G.; Johansson, G. Polygalacturonase is the key component in enzymatic retting of flax. J. Biotechnol. 2000, 81, 85-89. [CrossRef]

62. Azeri, C.; Tamer, U.; Oskay, M. Thermoactive cellulase-free xylanase production from alkaliphilic Bacillus strains using various agro-residues and their potential in biobleaching of kraft pulp. Afr. J. Biotechnol. 2010, 9, 1684-5315.

63. Kapoor, M.; Beg, Q.K.; Bhushan, B.; Singh, K.; Dadhich, K.; Hoondal, G. Application of an alkaline and thermostable polygalacturonase from Bacillus sp. MG-cp-2 in degumming of ramie (Boehmeria nivea) and sunn hemp (Crotalaria juncea) bast fibres. Process. Biochem. 2001, 36, 803-807. [CrossRef]

64. Tepe, O.; Dursun, A.Y. Exo-pectinase production by Bacillus pumilus using different agricultural wastes and optimizing of medium components using response surface methodology. Environ. Sci. Pollut. Res. 2014, 21, 9911-9920. [CrossRef]

65. Liang, C.; Gui, X.; Zhou, C.; Xue, Y.; Ma, Y.; Tang, S.-Y. Improving the thermoactivity and thermostability of pectate lyase from Bacillus pumilus for ramie degumming. Appl. Microbiol. Biotechnol. 2014, 99, 2673-2682. [CrossRef]

66. Qureshi, A.S.; Bhutto, M.A.; Chisti, Y.; Khushk, I.; Dahot, M.U.; Bano, S. Production of pectinase by Bacillus subtilis EFRL 01 in a date syrup medium. Afr. J. Biotechnol. 2012, 11, 12563-12570.

67. Ge, J.; Yang, Z.; Du, R.; Zhang, L.; Ping, W.; Zhao, D. Production of pectinolytic enzymes by two Bacillus spp. strains and their application in flax degumming. Trans. Tianjin Univ. 2019, 25, 413-419. [CrossRef]

68. Rehman, H.U.; Aman, A.; Nawaz, M.A.; Qader, S.A.U. Characterization of pectin degrading polygalacturonase produced by Bacillus licheniformis KIBGE-IB21. Food Hydrocoll. 2015, 43, 819-824. [CrossRef]

69. Embaby, A.M.; Masoud, A.A.; Marey, H.S.; Shaban, N.Z.; Ghonaim, T.M. Raw agro-industrial orange peel waste as a low cost effective inducer for alkaline polygalacturonase production from Bacillus licheniformis $\mathrm{SHG}_{10}$. SpringerPlus 2014, 3, 327. [CrossRef] [PubMed]

70. Remoroza, C.; Wagenknecht, M.; Buchholt, H.C.; Moerschbacher, B.M.; Gruppen, H.; Schols, H.A. Mode of action of Bacillus licheniformis pectin methylesterase on highly methylesterified and acetylated pectins. Carbohydr. Polym. 2015, 115, 540-550. [CrossRef] [PubMed]

71. Zhao, D.; Liu, P.; Pan, C.; Du, R.; Ping, W.; Ge, J. Bacterial succession and metabolite changes during flax (Linum usitatissimum L.) retting with Bacillus cereus HDYM-02. Sci. Rep. 2016, 6, 31812. [CrossRef] 
72. Torimiro, N.; Okonji, R. A comparative study of pectinolytic enzyme production by Bacillus species. Afr. J. Biotechnol. 2013, 12, 6498-6503. [CrossRef]

73. Namasivayam, E.; Ravindar, J.; Mariappan, K.; Akhil, J.; Mukesh, K.; Jayaraj, R. Production of extracellular pectinase by Bacillus cereus isolated from market solid waste. J. Bioanal. Biomed. 2011, 3, 70-75. [CrossRef]

74. Mukhopadhyay, A.; Dutta, N.; Chattopadhyay, D.; Chakrabarti, K. Degumming of ramie fiber and the production of reducing sugars from waste peels using nanoparticle supplemented pectate lyase. Bioresour. Technol. 2013, 137, 202-208. [CrossRef]

75. Liu, Y.; Chen, G.; Wang, J.; Hao, Y.; Li, M.; Li, Y.; Hu, B.; Lu, F. Efficient expression of an alkaline pectate lyase gene from Bacillus subtilis and the characterization of the recombinant protein. Biotechnol. Lett. 2011, 34, 109-115. [CrossRef]

76. Zhang, G.; Li, S.; Xu, Y.; Wang, J.; Wang, F.; Xin, Y.; Shen, Z.; Zhang, H.; Ma, M.; Liu, H. Production of alkaline pectinase: A case study investigating the use of tobacco stalk with the newly isolated strain Bacillus tequilensis CAS-MEI-2-33. BMC Biotechnol. 2019, 19, 45. [CrossRef]

77. Chiliveri, S.R.; Linga, V.R. A novel thermostable, alkaline pectate lyase from Bacillus tequilensis SV11 with potential in textile industry. Carbohydr. Polym. 2014, 111, 264-272. [CrossRef]

78. Mei, Y.; Chen, Y.; Zhai, R.; Liu, Y. Cloning, purification and biochemical properties of a thermostable pectinase from Bacillus halodurans M29. J. Mol. Catal. B Enzym. 2013, 94, 77-81. [CrossRef]

79. Ghazala, I.; Sayari, N.; Ben Romdhane, M.; Ellouz-Chaabouni, S.; Haddar, A. Assessment of pectinase production by Bacillus mojavensis I4 using an economical substrate and its potential application in oil sesame extraction. J. Food Sci. Technol. 2015, 52, 7710-7722. [CrossRef] [PubMed]

80. Duan, S.; Cheng, L.; Liu, Z.; Feng, X.; Zheng, K.; Peng, Y. Diversity and characteristics of kenaf bast degumming microbial resources. J. Nat. Fibers 2018, 15, 799-807. [CrossRef]

81. DeAngelis, K.M.; D’Haeseleer, P.; Chivian, D.; Fortney, J.L.; Khudyakov, J.; Simmons, B.; Woo, H.; Arkin, A.P.; Davenport, K.W.; Goodwin, L. Complete genome sequence of "Enterobacter lignolyticus" SCF1. Stand. Genom. Sci. 2011, 5, 69-85. [CrossRef]

82. Hasan, R.; Aktar, N.; Kabir, S.M.T.; Honi, U.; Halim, A.; Islam, R.; Sarker, M.D.H.; Haque, S.; Alam, M.; Islam, S. Pectinolytic bacterial consortia reduce jute retting period and improve fibre quality. Sci. Rep. 2020, 10, 5174. [CrossRef]

83. Datta, S.; Saha, D.; Chattopadhyay, L.; Majumdar, B. Genome comparison identifies different Bacillus species in a bast fibre-retting bacterial consortium and provides insights into pectin degrading genes. Sci. Rep. 2020, 10, 8169. [CrossRef]

84. Bugg, T.D.H.; Rahmanpour, R.; Rashid, G.M.M. Bacterial enzymes for lignin oxidation and conversion to renewable chemicals. In Production of Biofuels and Chemicals from Lignin; Springer Science and Business Media LLC: Berlin/Heidelberg, Germany, 2016; pp. 131-146.

85. Wu, Y.-R.; He, J. Characterization of anaerobic consortia coupled lignin depolymerization with biomethane generation. Bioresour. Technol. 2013, 139, 5-12. [CrossRef]

86. Chen, Y.; Chai, L.; Zhu, Y.; Yang, Z.; Zheng, Y.; Zhang, H. Biodegradation of kraft lignin by a bacterial strain Comamonas sp. B-9 isolated from eroded bamboo slips. J. Appl. Microbiol. 2012, 112, 900-906. [CrossRef]

87. Lee, C.H.; Khalina, A.; Lee, S.H.; Liu, M. A Comprehensive review on bast fibre retting process for optimal performance in fibre-reinforced polymer composites. Adv. Mater. Sci. Eng. 2020, 2020, 6074063. [CrossRef]

88. Antonov, V.; Marek, J.; Bjelkova, M.; Smirous, P.; Fischer, H. Easily available enzymes as natural retting agents. Biotechnol. J. 2007, 2, 342-346. [CrossRef] [PubMed]

89. Dreyer, J.; Müssig, J.; Koschke, N.; Ibenthal, W.-D.; Harig, H. Comparison of enzymatically separated hemp and nettle fibre to chemically separated and steam exploded hemp fibre. J. Ind. Hemp 2002, 7, 43-59. [CrossRef]

90. De Prez, J.; Van Vuure, A.W.; Ivens, J.; Aerts, G.; Van De Voorde, I. Cost-efficient enzymatic extraction, and treatment of natural fibres for high quality composites. In Proceedings of the MultiHemp Fibre Quality Workshop, Villeneuve d'Ascq, France, 18 January 2018.

91. Abdullah, S.; Zuhudi, N.; Anuar, N.; Isa, M. Mechanical and thermal characterization of alkali treated kenaf fibers. In Proceedings of the IOP Conference Series: Materials Science and Engineering, Batu Ferringhi, Penang, Malaysia, 21-22 November 2017; p. 012048.

92. Faruk, O.; Bledzki, A.K.; Fink, H.-P.; Sain, M. Biocomposites reinforced with natural fibers: 2000-2010. Prog. Polym. Sci. 2012, 37, 1552-1596. [CrossRef]

93. Réquilé, S.; Le Duigou, A.; Bourmaud, A.; Baley, C. Peeling experiments for hemp retting characterization targeting biocomposites. Ind. Crop. Prod. 2018, 123, 573-580. [CrossRef]

94. Favela-Torres, E.; Volke-Sepúlveda, T.; Viniegra-González, G. Production of hydrolytic depolymerising pectinases. Food Technol. Biotechnol. 2006, 44, 221-227.

95. Ovodov, Y.S. Current views on pectin substances. Russ. J. Bioorganic Chem. 2009, 35, 269-284. [CrossRef]

96. Song, K.H.; Obendorf, S.K. Chemical and biological retting of kenaf fibers. Text. Res. J. 2006, 76, 751-756. [CrossRef]

97. Nacos, M.; Katapodis, P.; Pappas, C.; Daferera, D.; Tarantilis, P.; Christakopoulos, P.; Polissiou, M. Kenaf xylan-A source of biologically active acidic oligosaccharides. Carbohydr. Polym. 2006, 66, 126-134. [CrossRef]

98. Kashyap, D.; Vohra, P.; Chopra, S.; Tewari, R. Applications of pectinases in the commercial sector: A review. Bioresour. Technol. 2001, 77, 215-227. [CrossRef]

99. Yu, P.; Zhang, Y.; Gu, D. Production optimization of a heat-tolerant alkaline pectinase from Bacillus subtilis ZGL14 and its purification and characterization. Bioengineered 2017, 8, 613-623. [CrossRef] 
100. Li, X.; Wang, H.; Zhou, C.; Ma, Y.; Li, J.; Song, J. Cloning, expression and characterization of a pectate lyase from Paenibacillus sp. 0602 in recombinant Escherichia coli. BMC Biotechnol. 2014, 14, 18. [CrossRef]

101. Saha, M.; Rana, R.S.; Adhikary, B.; Mitra, S. Screening of bacterial strains for pectate lyase production and detection of optimal growth conditions for enhanced enzyme activity. J. Appl. Nat. Sci. 2017, 9, 370-374. [CrossRef]

102. Boisset, C.; Chanzy, H.; Henrissat, B. Optimized mixtures of recombinantHumicola insolens cellulases for the biodegradation of crystalline cellulose. Biotechnol. Bioeng. 2000, 72, 339-345. [CrossRef]

103. Tamaru, Y.; Miyake, H.; Kuroda, K.; Nakanishi, A.; Matsushima, C.; Doi, R.H.; Ueda, M. Comparison of the mesophilic cellulosome-producing Clostridium cellulovorans genome with other cellulosome-related clostridial genomes. Microb. Biotechnol. 2010, 4, 64-73. [CrossRef] [PubMed]

104. Xu, R.; Zhang, K.; Liu, P.; Han, H.; Zhao, S.; Kakade, A.; Khan, A.; Du, D.; Li, X. Lignin depolymerization and utilization by bacteria. Bioresour. Technol. 2018, 269, 557-566. [CrossRef] [PubMed]

105. Huang, X.-F.; Santhanam, N.; Badri, D.V.; Hunter, W.J.; Manter, D.K.; Decker, S.R.; Vivanco, J.M.; Reardon, K.F. Isolation and characterization of lignin-degrading bacteria from rainforest soils. Biotechnol. Bioeng. 2013, 110, 1616-1626. [CrossRef] [PubMed]

106. Razali, N.; Salit, M.S.; Jawaid, M.; Ishak, M.R.; Lazim, Y. A study on chemical composition, physical, tensile, morphological, and thermal properties of roselle fibre: Effect of fibre maturity. BioResources 2014, 10, 1803-1824. [CrossRef]

107. Das, B.; Chakrabarti, K.; Ghosh, S.; Chakraborty, A.; Saha, M.N. Assessment of changes in community level physiological profile and molecular diversity of bacterial communities in different stages of jute retting. Pak. J. Biol. Sci. 2013, 16, 1722-1729. [CrossRef]

108. Liu, X.; Kokare, C. Microbial enzymes of use in industry. In Biotechnology of Microbial Enzymes; Academic Press: Cambridge, MA, USA, 2017; pp. 267-298.

109. Djemiel, C.; Grec, S.; Hawkins, S. Characterization of bacterial and fungal community dynamics by high-throughput sequencing (HTS) metabarcoding during flax dew-retting. Front. Microbiol. 2017, 8, 2052. [CrossRef]

110. Majumdar, B.; Das, S.; Saha, A.; Chowdhury, H.; Maitra, D.; Saha, M. Improved Retting of Jute and Mesta with Microbial Formulation; ICAR-Central Research Institute for Jute and Allied Fibres: Kolkata, India, 2013.

111. Kundu, A.; Chakraborty, A.; Alam Mandal, N.; Das, D.; Karmakar, P.G.; Singh, N.K.; Sarkar, D. A restriction-site-associated DNA (RAD) linkage map, comparative genomics and identification of QTL for histological fibre content coincident with those for retted bast fibre yield and its major components in jute (Corchorus olitorius L., Malvaceae s. 1.). Mol. Breed. 2015, 35, 19. [CrossRef]

112. Waldron, D.; Harwood, J. A preliminary investigation into the influence of chemical composition on the dynamic mechanical properties of flax (Linum usitattisimum) straw. J. Nat. Fibers 2011, 8, 126-142. [CrossRef]

113. Lam, T.B.T.; Hori, K.; Iiyama, K. Structural characteristics of cell walls of kenaf (Hibiscus cannabinus L.) and fixation of carbon dioxide. J. Wood Sci. 2003, 49, 255-261. [CrossRef]

114. Niture, S. Comparative biochemical and structural characterizations of fungal polygalacturonases. Biologia 2008, 63, 1-19. [CrossRef]

115. Sadrmanesh, V.; Chen, Y. Bast fibres: Structure, processing, properties, and applications. Int. Mater. Rev. 2019, 64, 381-406. [CrossRef]

116. Baker-Austin, C.; Dopson, M. Life in acid: pH homeostasis in acidophiles. Trends Microbiol. 2007, 15, 165-171. [CrossRef]

117. Preiss, L.; Hicks, D.B.; Suzuki, S.; Meier, T.; Krulwich, T.A. Alkaliphilic bacteria with impact on industrial applications, concepts of early life forms, and bioenergetics of ATP synthesis. Front. Bioeng. Biotechnol. 2015, 3, 75. [CrossRef]

118. Clark, J. Select the right fabric for liquid-solid separation. Chem. Eng. Prog. 1990, 86, 45-50.

119. Adamsen, A.P.S.; Akin, D.E.; Rigsby, L.L. Chemical retting of flax straw under alkaline conditions. Text. Res. J. 2002, 72, 789-794. [CrossRef]

120. Krall, S.M.; McFeeters, R.F. Pectin hydrolysis: Effect of temperature, degree of methylation, $\mathrm{pH}$, and calcium on hydrolysis rates. J. Agric. Food Chem. 1998, 46, 1311-1315. [CrossRef]

121. Foulk, J.; Akin, D.; Dodd, R. Influence of pectinolytic enzymes on retting effectiveness and resultant fiber properties. BioResources 2008, 3, 155-169.

122. Hoondal, G.; Tiwari, R.; Tewari, R.; Dahiya, N.; Beg, Q. Microbial alkaline pectinases and their industrial applications: A review. Appl. Microbiol. Biotechnol. 2002, 59, 409-418. [CrossRef] [PubMed]

123. Cao, J.; Zheng, L.; Chen, S. Screening of pectinase producer from alkalophilic bacteria and study on its potential application in degumming of ramie. Enzym. Microb. Technol. 1992, 14, 1013-1016. [CrossRef]

124. Zhang, L.; Zhu, R.; Chen, J.; Feng, X. Seawater-retting treatment of hemp and characterization of bacterial strains involved in the retting process. Process. Biochem. 2008, 43, 1195-1201. [CrossRef] 